\section{Social Work \& Education}

QSW\&E, 2021

UDC 378.013.42:364-43/:005.953.2

DOI: $10.25128 / 2520-6230.21 .1 .2$.

Слозанська, Г., Горішна, Н. (2021). Функціонування закладів інституційного догляду та ïх негативний вплив на їх вихованців. Social Work and Education. Vol. 8, No. 1. Ternopil-Aberdeen, 2021. pp. 19-41. DOI: 10.25128/2520-6230.21.1.2.

\title{
ФУНКЦІОНУВАННЯ ЗАКЛАДІВ ІНСТИТУЦЙНОГО ДОГЛЯДУ ТА ЇХ НЕГАТИВНИЙ ВПЛИВ НА ВИХОВАНЦІВ
}

\section{Ганна Слозанська,}

доктор педагогічних наук, доцент, завідувач кафедрою педагогіки та соціальної роботи,

ЗВО «Український католицький університет»,

м. Львів, Україна;

annaslozanska@gmail.com

ORCIDiD: https://orcid.org/00000002-8394-4925

\section{Надія Горішна,}

кандидат педагогічних наук, доцент, кафедра соціальної роботи, спеціальної освіти і менеджменту соціокультурної діяльності,

Тернопільський національний педагогічний університет імені Володимира Гнатюка, м. Тернопіль, Україна; nadiiahorishna@yahoo.com

ORCIDiD: https://orcid.org/00000002-9724-7098

Article history:

Received: January 9, 2021

1st Revision: January 27, 2021

Accepted: March 30, 2021
Анотація. У статті висвітлено особливості реалізації реформи деінституалізації, якою передбачено трансформацію системи інтернатних закладів та розвиток альтернативних форм сімейного виховання в Україні. Здійснено аналіз особливостей функціонування інтернатної системи в Україні, схарактеризовано проблеми, 3 якими стикаються вихованці, перебуваючи в інституційних закладах та ті, 3 якими вони стикаються після їх закінчення. Висвітлено результати аналізу праць українських та зарубіжних науковців, які доводять на негативний, згубний вплив інтернатних закладів на вихованців. Розкрито необхідність створення альтернативних форм виховання, наближених до сімейних, задля попередження потрапляння дітей в інтернатні заклади.

\begin{tabular}{lcr}
\multicolumn{1}{c}{ Ключові слова: інтернатні } & заклади; \\
вихованці & інтернатних & закладів; \\
деінституалізація; сімейні форми & виховання; \\
фахівець із соціальної роботи. &
\end{tabular}




\section{Вступ}

В Україні розпочався другий етап реформи деінституалізації, що стартувала у 2017 р. Процес заміни системи інституційного догляду та виховання дітей на систему, яка спрямована на забезпечення прав i найкращих інтересів дітей, збереження та підтримку сім’ї, створення належних умов для виховання та розвитку дітей у сім’ї або середовищі, максимально наближеному до сімейного $є$ основною метою реформи. Відомо, що для всебічного та гармонійного розвитку дитини необхідна сім'я, у якій формуються позитивні емоційні стосунки, забезпечуються догляд і виховання відповідно до віку, індивідуальних потреб і можливостей кожної дитини, вибудовуються ії світоглядні та моральні орієнтири, формуються уміння та навички, необхідні для успішної соціалізації. Базовими принципами реформи деінституалізації є: сім'я як найкраще середовище для виховання та розвитку дитини; збереження сім’і для дитини як головна умова забезпечення іiі благополуччя та найкращих інтересів; жодна дитина не повинна залишитись без уваги, іiі потреби, думка та інтереси мають бути враховані (Деінституалізація, 2020).

Однак, не усі діти в Україні, з різних причин, виховуються в сім'ях. Досі в державі існує рудимент радянського союзу - розгалужена мережа дитячих інтернатів.

В українській мові ми використовуємо поняття «інтернат» як узагальнене для назви різного типу закладів 3 цілодобовим перебуванням дітей, створених 3 метою їх проживання, розвитку, виховання, освіти, професійної орієнтації, підготовки до самостійного життя. Зазначимо, що саме поняття походить від латинського слова «іnternus» $i$ означає «внутрішній» (2020). У «Словнику української мови» (1970) подано таке визначення змісту означеного терміну: «гуртожиток для учнів і студентів навчального закладу; закритий шкільний заклад, у якому учні навчаються та живуть».

\section{Аналіз останніх досліджень і публікацій}

Питання доцільності існування інтернатних закладів як великих інституцій в яких діти живуть і виховуються стало особливо актуальним на початку XXI століття. Сьогодні низкою українських і зарубіжних науковців доведено шкоду, яку вони завдають своїм вихованцям і висвітлено проблеми, з якими стикаються випускники інтернатних закладів після їх закінчення. Зокрема, розгляд міжнародної практики реформування системи інтернатних закладів представлено у праці А. Машкаринець-Бутко (2019); особливості роботи спеціальних шкілінтернатів для дітей - С. Шевченко (2019); психологічні аспекти роботи 3 випускниками інтернатних закладів О. Воронкевич та С. Чопик (2019); аналіз факторів і ризиків, що впливають на ефективність реформи деінституціалізації закладів для дітей в Україні висвітлює В. Ніколаєва (2019). Основні аспекти 
реінтеграції, соціалізації та ресоціалізації вихованців інтернатних закладів в суспільство, сім’ї розкривають у своїх працях українські науковці, такі як Р. Білик (2019), 3. Кияниця (2008), І. Рогальська-Яблонська (2019), Н. Седляр (2017), М. Сокоринська (2019); на проблемі профілактики міжособистісних конфліктів підлітків в інтернатному закладі наголошує Ю. Кіптілая (2020); на неможливості виразити свої справжні почуття та ознаках насилля в інтернатах - I. Лідіян, О. Петер та П. Мосес (2020), Д. Мелі (2019). Однак, однією з найбільших проблем $\epsilon$ неготовність вихованців інтернатних закладів до створення сім'ї. на цьому акцентують увагу у своїх дослідженнях О. Заєць (2019), Г. Корінна (2019), Л. Єрьоміна (2019).

На незворотньо шкідливому впливі інтернатних закладів на своїх підопічних, ïх майбутнє життя наголошує у своєму дослідженні група науковців на чолі 3 М. Ван Інджендорном (van Ijzendoorn, M., Bakermans-Kranenburg, M., Duschinsky, R., ... \& Zeanah, C. (2020). На основі аналізу наукової літератури з проблем дитячої інституалізації та деінституалізації з позиції глобальної перспективи учені прийшли до висновку про міцний негативний зв'язок між інституційним доглядом дітей і їхнім розвитком, акцентуючи увагу на відставанні у психічному, когнітивному і поведінковому аспектах. Важливий, проте менш помітний, зв'язок виявлено між інституалізацією та соціоемоційним розвитком дітей, їх психічним здоров'ям. Дослідниками доведено, що чим довший термін перебування дітей в закладах інституційного догляду тим більший ризик виникнення несприятливих для них наслідків в плані психологічного розвитку і тим менше у них шансів на одужання. Тому максимум зусиль суспільства і сучасна політика усіх країн світу мають бути спрямовані на мінімізацію потрапляння дітей в інституційні заклади та максимізацію ї виходу з інтернатів. До такого висновку прийшли вчені в результаті проведеного дослідження (van Ijzendoorn, M., Bakermans-Kranenburg, M., Duschinsky, R., ... \& Zeanah, C. (2020).

Мета статті - на основі аналізу наукової літератури українських і зарубіжних дослідників, нормативно-правової бази розкрити специфіку діяльності інтернатних закладів в Україні та визначити вплив великих установ інституційного догляду на особистість вихованця.

\section{Методологія дослідження}

Для досягнення поставленої мети було використано метод аналізу документів, що передбачав пошук, відбір, аналіз та узагальнення даних статистичних та аналітичних звітів, нормативно-правових документів, наукових статей, тез конференцій та інших матеріалів 3 теми дослідження. Пошук документів здійснювався у наукометричних базах даних «Законодавство України», Web of 
Science, PsycINFO, Google Scholar та ResearchGate, на офіційних веб-сайтах органів державної влади та місцевого самоврядування.

Для пошуку використовувались ключові слова англійською та українською (інтернат, інтернатний заклад, заклад інтернатного типу, школа-інтернат, інституалізація, інституційний догляд, діти, позбавлені батьківського піклування, вихованці інтернатних закдадів, деінституалізація) та англійською (orphanages, boarding schools, instutualization, children in institutions, children in residential care, exiters of boarding schools, deinstutualization) мовами та їх різні комбінації. Відбір документів для подальшого аналізу здійснювався за наступними критеріями: відповідність темі дослідження, наявність повнотекстового документу; та принаймні двох посилань на первинні джерела інформації (для наукових публікацій).

Одиницями аналізу у відібраних документах виступали окремі фрагменти тексту, ідея яких відповідала визначениим категоріям дослідження: функціонування інтернатних закладів, проблеми вихованців інтернатних закладів, деінституалізація інтернатних закладів.

\section{Основна частина}

\section{Функціонування інтернатних закладів в Украйні}

У сучасних умовах в Україні поки діють різні типи інтернатних закладів (Звіт про здійснення Уповноваженим Президента України з прав дитини..., 2021), що надають різні роду соціальні, освітні, медичні, економічні та інші послуги дітям та підліткам, які в них перебувають на постійній або тимчасовій умовах відповідно до вимог, встановлених чинним законодавством.

Аналіз статистичних даних свідчить, що станом на 2018 р. в Україні функціонував 751 інтернатний заклад, в яких перебувало 106700 дітей; у 2019 р. - 718 таких установ, в яких жило та виховувалося 102570 дітей. При цьому 92,3\% 3 них мали хоча б одного з батьків, і лише 7,7\% - є статусними дітьми. 3 них 38 інтернатних закладів (2 834 вихованців) станом на 2019 р. підпорядковувалися Міністерству охорони здоров'я (МО3), 555 (93 506 вихованців) - Міністерству освіти і науки $(\mathrm{MOH})$ та 125 (6 230 дітей) - Міністерству соціальної політики (МСП) (Національна стратегія ..., 2021; Про хід виконання указів та доручень ..., 2021). Відомо, що в інтернатних закладах системи МОЗ живуть і виховуються найменші діти, МСП - діти 3 інвалідністю. Однак, найбільша кількість інтернатних закладів та дітей в них - у системі Міністерства освіти і науки.

У порівнянні 3 Європою в Україні значно вищий відсоток дітей $\epsilon$ інституціолізованими. Зокрема, за останніми статистичними даними, в Україні $1,4 \%$ дитячого населення перебувають в інтернатах. В одному інституційному закладі, в середньому, живуть та виховуються від 100 до 300 дітей; 17,2\% дітей, які перебувають в інтернатах, мешкають більше як по 9 осіб у кімнаті. Тоді як в 
Австрії, Норвегії - 0,1\% дитячого населення перебувають в інституційних установах; у Болгарії, Молдові, Польщі та Румунії - 0,5\%. Позитивною є і статистика Європи щодо кількості дітей в одному закладі - 6-12 дітей.

Україна витрачає на утримання інтернатних закладів значні кошти, абсолютна більшість $з$ яких йде не на речі чи продукти харчування для дітей - а на утримання будівель та оплату праці персоналу. Так, 7 мільярдів гривень було виділено на усі інтернатні заклади у 2016 р. та 8 мільярдів - у 2017 р.. Ще 250 мільйонів гривень у 2016 p. і 234 мільйонів - у 2017 р. надійшло від благодійників. 3 цієї суми $80 \%$ було витрачено на оплату комунальних послуг й утримання величезних споруд, виплату заробітної плати співробітникам інтернатів. Варто зазначити, що такі великі витрати на персонал в інтернатних закладах зазичай не оправдовується, оскільки майже половину коштів (46\%) витрачають на оплату праці технічного й адміністративного персоналу, тоді як на оплату праці вихователів і вчителів - близько $54 \%$ (Реформа інтернатних закладів, 2020). При цьому наповнюваність інтернатних закладів становить 15-70 $\%$ (На утримання інтернатів, 2021).

За таких обставин, одним із основних завдань державної соціальної політики $\epsilon$ зменшення кількості закладів інтернатного типу та кількості вихованців у них. Цьому сприяє реформа «деінституалізації», розрахована на 10 років. В ході іiі реалізації забезпечується динамічний розвиток і доступність послуг на рівні об'єднаних територіальних громад для дітей та сімей $з$ дітьми відповідно до їх індивідуальних потреб, створення ринку соціальних послуг тощо. Це сприятиме поетапній ліквідації інтернатних закладів.

Для підсилення деінституалізації, урядом країни схвалено Національну стратегію реформування системи інституційного догляду та виховання дітей на 2017-2026 pp. і план заходів з іiі реалізації. Відповідно до Національної стратегії, вже у 2026 р. в інституціях дітей має бути менше $0,5 \%$ від загальної кількості дитячого населення (зараз - 1,5\%). А ті діти, хто за різних причин все ж залишаться в інституціях, а не в сім'ях - житимуть у невеликих установах в умовах, максимально наближених до сімейних (до 10 осіб в одному закладі). У кожній громаді мають 3'явитися доступні й якісні послуги для сімей 3 дітьми. Буде існувати ринок цих послуг, не менше 50\% 3 яких будуть надавати професійні громадські організації.

\section{Проблеми, з якими стикаються вихованці інтернатних закладів}

Реформа деінституалізації передбачає створення таких умов на рівні територіальних громад, за яких дитина б жила та виховувалася в сім'ї або формах, наближених до сімейних.

Науці відомо безліч досліджень, які свідчать про шкідливість перебування і вихованні дітей в інтернатних закладах для їх психічного, інтелектуального, 
емоційного, мовленнєвого та фізичного розвитку. Особливо небезпечним воно $\epsilon$ для дітей віком від 0 до 3 років, на який припадає найважливіша фаза розвитку в житті. Перебування в інтернаті наносить невиправну шкоду мозку дитини; часто стає причиною формування розумової відсталості та соціально-педагогічної занедбаності. Зокрема, перебування дітей в інтернаті з раннього віку спричиняє затримку у $55 \%$ загальних моторних навичок, у $40 \%$ - розвитку дрібної моторики, у $32 \%$ - розумового і $43 \%$ - мовного, $28 \%$ - емоційного розвитку, $44 \%$ дітей мають затримку одразу за трьома і більше показниками (Реформа інтернатних закладів, 2020).

Діти, які виховуються в інтернатних закладах, часто мають труднощі у спілкуванні та поведінці, характеризуються звуженням світогляду, нездатністю до особистісного зростання, невмінням адаптуватися до нових умов життедіяльності, соціалізуватися та інтегруватися в суспільство (Психологічні аспекти роботи 3 дітьми-сиротами в умовах інтернатного засладу, 2008), відстають у когнітивному, емоційному розвитку від своїх однолітків, які зростають в сім'ях.

Вихованці інтернатних закладів мають низку психологічних проблем. Перебування дитини в умовах інтернату має негативний вплив на психіку дитини, що саме перебуває у стадії розвитку та формування різноманітних рис характеру, навичок спілкування, подолання життєвих проблем тощо.

Дослідження (Дерябо, 1999; Балакієва, Яременко, Дудар, 2000) свідчать, що вихованці інтернатних закладів характеризуються високим рівнем тривожності, імпульсивності, агресивності, нестійкою, неоднозначною самооцінкою, наявністю комплексу неповноцінності, відчуття малоцінності своєї особистості; деформованістю емоційної сфери; відсутністю позитивного ставлення до здоров'я та несформованістю уявлень про способи його збереження; невмінням спілкуватися та встановлювати контакти з однолітками і дорослими; відсутністю життєвих навичок; нездатністю швидко самостійно приймати рішення, долати життєві труднощі та проблеми.

Науковці (Ящук, 2001) підтверджують несформованість життєвої компетентності у вихованців інтернатних закладів як здатності правильно оцінювати складні економічні, соціально-культурні, виробничі ситуації, приймати правильні рішення й діяти згідно з обставинами соціального, культурного й економічного життя суспільства; успішно самореалізуватися, виконанувати найважливіших функції життедіяльності, забезпечувати фізичні, психічні та духовні потреби. На думку Ю. Бондаренко (2009) та Е. Кузьмина (2011) життєва компетентність вихованця інтернатного закладу є інтегральною характеристикою особистості, що визначає його спроможність у вирішенні життєвих проблем через усвідомлення їх цінності й сутності; засвоєння загальноприйнятих норм і правил їх вирішення; ціннісне ставлення до оволодіння досвідом реалізації різновидів 
життєдіяльності на основі наявних знань, умінь, навичок і особистісних якостей (Бондаренко, 2009; Кузьмина, 2011).

Внаслідок несформованої життєвої компетентності вихованці інтернатних закладів $\epsilon$ «соціально незрілими». Результати дослідження, проведеного Л. Канішевськоюм (2012), засвідчили, що значна більшість (32,4\%) старшокласників інтернатних закладів $€$ соціально індиферентними 3 низьким рівнем сформованої соціальної зрілості. Тобто, у них несформовані соціальні настанови, спрямовані на свідому реалізацію суспільних норм і цінностей; соціальні якості; не засвоєнні основні соціальні ролі, що дозволяють їх компетентно діяти в усіх сферах суспільного життя.

Позбавлення дитини батьківського піклування, виховання в умовах школиінтернату спричиняють появу у неї соціальної деривації, що спричиняє відмежування від соціальних зв'язків 3 навколишнім світом, призводить до формування принципово інших механізмів іiі активності, входження у суспільне оточення (Дементьєва, 2003). Депривація, на думку А. Машкаринець-Бутко (2013), ускладнює процес формування самої особистості як унікального і неповторного феномена, погіршує встановлення суспільно значущих стосунків через нестачу міжособистісних взаємин на рівні «батьки-діти».

Доведено, що діти в інтернатних закладах наражаються на підвищений ризик насильства в порівнянні з іншими. Дослідження О. Шелевер (2014) засвідчує, що переважна більшість вихованців інтернатних установ відчувала всі види насильства. Найчастіше діти страждали від моральної жорстокості (близько 75\%), психічного (близько 60\%), фізичного (близько 55\%) і сексуального (близько 10\%) видів насильства. Здебільшого, свій гнів найчастіше проявляли до більш слабких, молодших за віком дітей та тварин.

Різновидом насильства є булінг. Більшість дітей, які перебувають у закладах закритого типу, якими є інтернатні заклади, страждають від булінгу. Група науковців на чолі 3 А. Мацонні (2017) провела емпіричне дослідження щодо можливих випадків боулінгу по відношенню до дітей, які перебувають в закладах інституційного типу Болгарії, Греції, Румунії та Франції. Результати дослідження засвідчили, що 50 \% вихованців інтернатів страждають від булінгу. Не $є$ виключенням і Україна. В аналітичному звіті, опублікованому за результатами соціологічного опитування, проведеного фахівцями Українського інституту соціальних досліджень імені Олександра Яременка, висвітлено окремі дані щодо наявності боулінгу у закладах інтернатного типу. Звітом підтверджено факти порушення прав дітей, жорстокого поводження, насильства, наявності конфліктів між вихованцями, між вихованцями і вихователями інтернатних закладів України (Гордієнко, 2018). Про наявність знущань старших вихованців по відношенню до молодших, особливо з числа дітей-сиріт, мова йде і у дослідження Н. Гордієнко (2018), у якому взяло участь 634 учні 8-11 класів 14 шкіл-інтернатів. 
Вагомою проблемою $є$ також те, що діти, які перебувають в інтернатних закладах понад 10 років, не мають сформованої прив'язаності до батьків або близьких родичів (Методичні рекомендації щодо удосконалення утримання та виховання дітей у дитячих інтернатних закладах ..., 1998). Відсутність значущої особи в житті дитини, прикладу для наслідування не дає змоги усвідомити, сформувати життєві орієнтири. Саме тому, випускники інтернатних закладів $€$ непідготовленими до самостійного життя, не мають необхідних соціальних умінь і навичок (Бережна, 2013; Улунова, 2006). 90 \% з них не можуть реалізувати себе у житті, не створюють власних сімей. У 75\% вихованців інтернатних закладів виявлено низький рівень психологічної готовності до створення сім'ї (Кізь, 2003; Грітчина, 2011). Причиною цього $є$ середовище інтернатного закладу, яке не сприяє формуванню в дитини здатності вибудовувати стосунки протягом життя.

Встановлено, що інтернатна модель виховання $є$ звичною моделлю для дітей матері, яких у дитинстві виховувались в інтернаті.

Зростаючи у великих установах інституційного догляду, діти не набувають достатніх навичок для успішної соціальної інтеграції. Статистика свідчить, що $20 \%$ випускників інтернатних закладів мають судимість, $14 \%$ - займаються проституцією, $10 \%$ - протягом двох років після випуску здійснюють самогубство, і лише $10 \%$ - повністю інтегруються у суспільство, $50 \%$ - схильні до насильства та правопорушень, а 23\% взагалі можуть стати безхатченками (Чому інтернати шкідливі для дітей, 2021).

Аналіз низки труднощів, з якими стикають вихованці інтернатних закладів, дозволив Л. Канішевській (2007), О. Лебєдєвій та Н.Неупокоєвій (2002) структурувати їх у п'ять груп:

- проблеми соціально-побутового характеру: вихованці мають обмежені уявлення про можливості догляду за собою, приготування їжі, прибирання оселі, реалізації соціальних ролей, подолання різноманітних бар'єрів тощо;

- проблеми соціально-трудового характеру: у вихованців інтернатів недостатньо розвинуті знання, уміння й навички самообслуговування;

- проблеми соціально-економічного характеру: у вихованців відсутні уміння придбання товарів, досвід планування й розподілу грошей тощо;

- проблеми комунікативного характеру: вихованців $є$ відчуженими, з низьким рівнем мотивації, спілкування, вміння розуміти партнера тощо;

- проблеми щодо збереження й зміцнення здоров'я: вихованці характеризуються безвідповідальним ставленням до власного здоров'я та здоров'я оточуючих, мають неповні уявлення щодо змісту й структури здорового способу життя.

На основі аналізу досліджень українських і зарубіжних учених, нами виділено групи проблем, пов'язані з інтелектуальним, моральним та емоційним розвитком вихованців інтернатних закладів. 


\section{Життя та виховання дітей в інтернатних установах}

Безперечно, життя в інтернаті має негативний, згубний вплив на особистість дитини. Інституалізація в досить ранньому віці веде до незворотних змін і непоправних наслідків в дорослому житті. Неможливість соціалізуватися, інтегруватися в суспільство, знайти себе в особистісному та професійної плані, створити сім'ю, засвоїти нові суспільно значимі ролі $є$ для більшості випускників інтернатних закладів великою проблемою.

Закритість, ізоляція від навколишнього світу $є$ характерним станом для вихованців інтернатів. Розрив з родиною, відсутність взаємодії, спілкування 3 родичами, позитивної моделі сім'ї, самотність, нестача тепла та любові, втрата індивідуальності, насильство, приниження та нівелювання особистості, неготовність до самостійного життя через відсутність відповідних необхідних навичок, відставання в інтелектуальному, емоційному, фізичному розвитку, труднощі у спілкуванні $\epsilon$ кричущими проблемами, 3 якими стикаються випускники інтернатів після їх закінчення. Причиною цьому сьому є устрій самих інтернатів, система групової взаємодії, колективізму в них, життя за чиїмось графіком і відповідно до чиїхось розпоряджень.

Значна частина дітей перебуває в інтернатних закладах за заявами батьків через їхню нездатність задовольнити потреби дитини, через хворобу, бідність чи безробіття тощо. Основними причинами вилучення дітей з сім’ї і розміщення їх в інтернатних закладах, є: бідність; відсутність підтримуючих послуг на рівні об'єднаних територіальних громад для сімей у складних життєвих обставин; відсутність можливостей для реалізації інклюзивної освіти для дітей 3 особливими освітніми потребами; дискримінація окремих категорій населення (наприклад, діти з інвалідністю, діти з етнічних меншин) у громаді; відсутність комплексних соціальних послуг, які б надавалися відповідно до потреб жителів об'єднаних територіальних громад. Розміщення дитини в спеціалізованих інтернатних закладах розглядається батьками як єдина можливість забезпечити належний догляд за нею, iї освітнє виховання й утримання. Проте, чинна система виховання в таких закладах не забезпечує належних умов для повноцінного розвитку дитини, перешкоджає iї адаптації у суспільстві, порушує право на доступ до якісної освіти відповідно до інтересів та можливостей дитини.

Для окремих сімей, на їхню думку, наявність у країні мережі інтернатних закладів є так званим «рятівним кругом», «спокусою», можливістю «позбутися проблем 3 дитиною». Віддавши дитину на виховання у державний інтернатний заклад сама сім'я, інколи діючі соціальні служби, установи й організації намагаються таким чином вирішити проблеми самої сім'ї. При цьому, ніхто не задумується про шкоду, яку несе діючий підхід самій сім'ї та суспільству, про 
страшні наслідки для самої дитини та про альтернативні можливі шляхи вирішення проблем кризових сімей або сімей у СЖО.

Щорічно держава витрачає понад 5,7 млрд. грн. на фінансування інтернатів. Однак, лише $10 \%$ цих коштів витрачається безпосередньо на потреби дитини. Вважаємо, варто і доцільніше скерувати ці кошти на підтримку сімей, профілактику складних життєвих обставин, реалізацію заходів, що унеможливлять потрапляння дітей в інтернатні заклади. Запровадження комплексу соціальних послуг на рівні об'єднаний територіальних громад для сімей з дітьми із врахуванням їхніх потреб (Слозанська, 2016) також допоможе попередити потрапляння дітей в інтернатні установи.

Деінтитуалізація та розвиток соціальних послуг для сімей з дітьми на рівні об'сднаних територіальних громад

Суть деінституціалізації та трансформації соціальних послуг для дітей, що має місце в сучасних умовах в Україні, полягає у тому, що відмовитися від системи інституційного догляду і перейти до створення альтернативних форм сімейного виховання та надання низки інтегрованих соціальних послуг з їх підтримки на рівні об'єднаної територіальної громади. Під «інституційним доглядом» розуміють організацію стаціонарного догляду за дітьми без батьків чи опікунів терміном понад три місяці у закладі, кількістю 25 дітей і більше (Browne et al., 2004, 2005a).

Деінституціалізація - це комплексна діяльність, систематичні, стратегічно обгрунтовані зміни, що, в майбутньому, приводять до зменшення залежності від стаціонарного догляду дітей та зростання чутливих послуг з догляду, підтримки для сімей $з$ дітьми у громадах. Базовими компонентами реформи є: попередження направлення та перебування дітей в закладах інституційного догляду; запровадження належного альтернативного догляду за дитиною на рівні громади; вдосконалення на рівні громади послуг для дітей та сімей $з$ дітьми, які потребують державного догляду; реалізація довгострокових планів 3 догляду і постійного влаштування в замісні родини для дітей, чиї батьки нездатні піклуватися про них (Деінституціалізація та трансформація послуг для дітей, 2009, с. 35).

Розвиток якісних соціальних послуг з підтримки, догляду сімей 3 дітьми за місцем їхнього проживання, впровадження альтернативних форм виховання, наближених до сімейних сприяють запобіганню розриву сімейних зв'язків та попередженню соціального сирітства. За таких умов виникає необхідність у реалізації сімейно орієнтованого підходу (Горішна, 2019; Петрочко, 2016) на рівні територіальної громади.

Впровадження посад фахівців з соціальної роботи на рівні об'єднаних територіальних громад дозволить вчасно виявляти кризові сім’і, надавати якісні і доступні соціальні послуги відповідно до їхніх потреб, на основі оцінки проблем дітей і сімей з дітьми, наявних ресурсів розробляти ефективні програми втручання 
(Слозанська, 2017). Впродовж 2014-2020 pр. були розроблені відповідні нормативно-правові акти, що регулюють процес діяльності соціального працівника та надання соціальних послуг (Слозанська, 2017). Кваліфікований фахівець 3 соціальної роботи відіграє значну роль у профілактиці СЖО у ТГ через надання послуги з раннього втручання, що, в свою чергу, превентує потрапляння дітей в інституційні заклади (Кияниця, \& Петрочко, 2017).

Безперечно важливе значення у профілактиці інституалізації дітей має розробка та запровадження якісних соціальних послуг на рівні ТГ. Законодавством України передбачено 17 базових соціальних послуг, які можуть надавати фахівці з соціальної роботи відповідно до потреб самих споживачів. Однак, серед них $є$ ті, які на нашу думку, є найбільш затребуваними в умовах реалізації реформи деінституалізації.

Оскільки найчастіше дитина опиняється в інтернатному закладі через власні проблеми зі здоров'ям або інвалідність когось із близьких родичів, смерть батьків, нездатність батьків піклуватися про своїх дітей через бідність, недосвідченість, ранню вагітність. Тому впровадження таких послуг як послуга раннього втручання, денного догляду, «батьківського перепочинку», альтернативних форм сімейного виховання дозволить профілактувати інституалізацію дітей.

Послуга раннього втручання надається сім'ям, у яких народилась дитина 3 особливими потребами, або ж якщо в дитини виявлено порушення в розвитку чи $\epsilon$ ризик виникнення порушення на рівні ТГ. Міждисциплінарна команда фахівців (фахівець з соціальної роботи, психолог, реабілітолог, педіатр, логопед тощо) працює з сім'єю та дитиною комплексно за місцем проживання для того, щоб допомогти та підтримати сім'ю та дитину, навчити їх використовувати власні можливості для розвитку і повноцінного існування кожного члена сім'ї.

Послуга денного догляду полягає в тому, що дитину впродовж дня доглядають кваліфіковані фахівці, працюють із ії реабілітацією, соціалізацією і навчанням тощо. Це допомагає батькам вивільнити час для роботи та вирішення інших проблем.

Послуга «батьківського перепочинку» надається сім'ям, які виховують дітей 3 особливими потребами. Команда кваліфікованих фахівців працює певний час 3 дитиною для того, щоб дати батькам можливість перепочити

Розвиток та запровадження на рівні ТГ альтернативних форм сімейного виховання $є$ необхідним, особливо якщо виникають кризові ситуації та $є$ загроза вилучення дитини з сім'ї. Сім'я патронатних вихователів (Зубейко, \& Василів, 2018 ) - це тимчасова форма влаштування дитини (до 3 місяців, максимум - до 6) у сім'ю патронатних вихователів на час, коли фахівці з соціальної роботи працюють з біологічної родиною і допомагають їм подолати кризу. 
Опікунські, прийомні сім'ї або дитячі будинки сімейного типу створюються для дітей, яких неможливо віддати в біологічну сім'ю, або для тих, хто залишились без батьківського піклування чи втратив батьків (Круглова, \& Тищенко, 2014).

Малі групові будинки як альтернатива великим інституційним закладам мають право на існування. Це невеликі заклади для 10 дітей, які не всиновлені і не повернені в рідні сім'ї або не влаштовані у сімейні форми виховання.

Вагому нішу між дітьми і сім'ями 3 дітьми та соціальними послугами в ОТГ займає інклюзивна освіта. Неможливість задовольнити проблеми дітей 3 особливими освітніми потребами на рівні ТГ є однією 3 основних причин потрапляння ї у інтернатні заклади. Створення умов для забезпечення доступності для дітей з особливими освітніми потребами до якісної освіти, забезпечення рівних можливостей, збільшення їх участі у соціальних процесах сприятиме процесу деінституалізації дітей та вихованню їх у сім'ї або альтернативних формах сімейного виховання.

\section{Висновки}

Реформа деінституалізації, що має місце в Україні передбачає внесення якісних змін у систему інституційного догляду дітей та впровадження альтернативних форм сімейного виховання. Підстав для трансформації інтернатних завладів $\epsilon$ декілька. Перша, та одна з головних - це те, що самі інтренати мають негативний вплив на своїх вихованців. Перебувають в закладах інституційного догляду діти можуть страждають від низки психологічних та соціальних проблем, мають проблеми 3 соціалізацією, інтеграцією у суспільство, самовизначенням та професійною ідентифікацією, створенням сім'ї, засвоєнням суспільно значимих ролей, можуть страждати від різних видів насильства тощо. Водночас, держава тратить значну суму коштів на фінансування закладів, тоді як значно ефективніше витрачати ці гроші на фінансування соціальних послуг на рівні громад, які б превентували інституалізацію дітей та сприяли їх вихованню в сім'ї.

\section{References}

Балакірева, О. М., Яременко, О. О., Дудар, Н. П. та ін. (2000). Вихованці інтернатів про себе і своє життя. К.: Український інститут соціальних досліджень, Кн. $1.134 \mathrm{c}$.

Бережна, Л. (2013). До проблеми соціалізації дітей-сиріт та дітей, позбавлених батьківського піклування, у закладах інтернатного типу. Гуманітарний вісник Державного вищого навчального закладу Переяслав-Хмельнищький державний педагогічний університет імені Г.С. Сковороди. Педагогіка. Психологія. Філософія, (28 (1)), 14-18. 
Білик, Р. М. (2019). Соціалізація вихованців закладів інтернатного типу як соціально-педагогічна проблема. Bulletin of the Cherkasy Bohdan Khmelnytsky National University. Series" Pedagogical Sciences", (10-11).

Бондаренко, Ю. (2009). Життєва компетентність вихованців закладів інтернатного типу. Педагогіка формування творчої особистості у вищій $i$ загальній школі. Запоріжжя, (2), 52-56.

Гордієнко, Н. (2018). Проблема булінгу в учнівських колективах інтернатних навчальних закладів: соціологічний аспект. Evropsky politicky a pravni diskurz, (5, Iss. 1), 201-209.

Горішна, Н. М. (2019). Сімейно-орієнтований підхід до надання соціальних послуг сім'ям, які виховують дітей з інвалідністю. Соиіологія та соиіальна робота в умовах начіональних та регіональних вимірів, 11(1), 24-25.

Грітчина, А. I. (2011). Зміст, форми і методи формування готовності юнаків шкіл-інтернатів до виконання ролі майбутнього сім'янина. Теоретико-методичні проблеми виховання дітей та учнівської молоді: 3б. наук. праць,, 2(15), 134-141.

Деінституціалізація та трансформація послуг для дітей. (2009). К.: Видавничий дім «Калита», $193 \mathrm{c}$.

Деінституціалізація. (2020). [Електронний ресурс]. Режим доступу: https://www.msp.gov.ua/timeline/Deinstitucializaciya.html.

Дементьева, И. (2003). Социальная адаптация детей-сирот. Социальная педагогика. № 2., 64-73.

Дерябо, С., \& Ясвин, В. (1999). Отношение к здоровью и к здоровому образу жизни: методика измерения. Директор школьы. № 2., 7.

Єрьоміна, Л. Є. (2019). Соиіально-педагогічні умови формування у вихованиів закладу інтернатного типу готовності до сімейного життя (Doctoral dissertation, Національна академія педагогічних наук України).

Заєць, О. М. (2019). Психологічна готовність вихованців інтернатних закладів до створення сім'ї. Рекомендовано Вченою радою Ніжинського державного університету імені Миколи Гоголя (НДУ імені Миколи Гоголя) Протокол № 4 від 24.10. 2019 p., 30.

Звіт про здійснення Уповноваженим Президента України з прав дитини моніторингового дослідження стану функціонування закладів для дітей-сиріт та дітей, позбавлених батьківського піклування, дітей, які не мають необхідних умов для виховання та навчання в сім'ї, дітей з особливими потребами, ефективність використання такими закладами бюджетних коштів, спрямованих на забезпечення їх діяльності (на виконання Доручення Президента України № 11/1852 від 22 липня 2013 року). (2021). [Електронний ресурс]. Режим доступу: http://www.president.gov.ua/news/27816.html.

Зубейко, Г., \& Василів, С. С. (2018, October). Патронат як форма влаштування дітей позбавлених батьківського піклування. In 76-та Студентська науково- 
технічна конференція. Секиія права та психології: збірник тез доповідей (pp. 149150). Видавництво Львівської політехніки.

Канішевська, Л. В. (2012). Дослідження проблеми виховання соціальної зрілості старшокласників шкіл-інтернатів. Педагогічний альманах, (16), 213-220.

Канішевська, Л.В.(2007). Науково-методологічні основи формування життевої компетентності вихованців інтернат них закладів. Формування життєвої компетентності вихованциів у закладах інтернатного типу: наук.метод. посіб. К.: Педагогічна думка, 5-36.

Кияниця, 3. П. (2008). Соціально-педагогічні аспекти роботи служби реінтеграції та соціалізації випускників інтернат них закладів як складової структури інтегрованих соціальних служб для вразливих дітей та сімей. 79 -84.

Кияниця, 3. П., \& Петрочко, Ж. В. (2017). Соціальна робота з вразливими сім'ями та дітьми: пос. у 2-х ч.; Ч. 1. Сучасні орієнтири та ключові технології.

Кізь, О.Б. (2003). Формування психологічної готовності вихованців інтернатних закладів до створення сім'ї.

Кіптілая, Ю. В. (2020). Соціально-педагогічна профілактика міжособистісних конфліктів підлітків в інтернатному закладі.

Корінна, Г. О. (2019). Готовність вихованців закладів інтернатного типу до сімейного життя як соціально-педагогічна проблема. Bulletin of the Cherkasy Bohdan Khmelnytsky National University. Series" Pedagogical Sciences", (10-11).

Круглова, О. О., \& Тищенко, І. О. (2014). Роль інституту опіки і піклування у забезпеченні прав та інтересів дітей у сучасних умовах. Науковий вісник Дніпропетровського державного університету внутрішніх справ, (4), 159-165.

Кузьмина, Е. (2011). Специфіка формування життєвої компетентності вихованців інтернатних закладів. Редакційна рада, 103.

Лебедев, О.Е., \& Неупокоева, Н. И. (2002). Цели и результаты школьного образования: метод. реком. СПб.: СПГУПМ, 52 с.

Матеріал 3 Вікіпедіï https://uk.wikipedia.org/wiki/\%D0\%A8\%D0\%BA\% D0\%BE\%D0\%BB\%D0\%B0-\%D1\%96\%D0\%BD\%D1\%82\%D0\%B5\%D1\%80\%D0\% $\mathrm{BD} \% \mathrm{D} 0 \% \mathrm{~B} 0 \% \mathrm{D} 1 \% 82$.

Машкаринець-Бутко, А. (2013). Особливості розвитку дітей-вихованців загальноосвітніх шкіл-інтернатів. Науковий вісник Ужгородського національного університету. Серія: Педагогіка. Соціальна робота, (27), 116-119.

Машкаринець-Бутко, А. (2019). Розгляд міжнародної практики реформування системи інтернатних закладів та акумулювання цього досвіду для Закарпаття.

Мета деінституціалізації - реалізація права кожної дитини на сім'ю: Міністерство соціальної політики. URL: https://www.msp.gov.ua/news/15560.html (дата звернення: 08.11.2019).

Методичні рекомендації щодо удосконалення утримання та виховання дітей у дитячих інтернатних закладах на принципах, що базуються на Конвенції ООН 
про права дитини. (1998). [упор.: Л.С. Волинець, О. Г. Антонова-Турченко, І. Б. Іванова, Н. М. Комарова, І.В. Пєша, С. М. Трусова]. К.: Студцентр, 190 с.

На утримання інтернатів йде 7,7 млрд на рік, до дітей доходить 15\%. (2021). [Електронний ресурс]. Режим доступу: http://nbnews.com.ua/ua/news/103058/.

Національна стратегія реформування системи інституційного догляду та виховання дітей на 2017-2026 pp.

Національна стратегія реформування системи інституційного догляду та виховання дітей на 2017-2026 pp. (2021). [Електронний ресурс]. Режим доступу: https://mon.gov.ua/ua/osvita/zagalna-serednya-osvita/navchannya-ditej-u-specialnihzakladah-osviti/nacionalna-strategiya-reformuvannya-sistemi-internativ

Острович, Э. С. (2018). Загальна характеристика процесу деінституалізації в Україні. Прикарпатський юридичний вісник, 2 (1 (22)), 35-39.

Петрочко, Ж. В. (2016). Сімейно орієнтований підхід у соціальній роботі. Наукові записки [Ніжинського державного університету ім. Миколи Гоголя]. Психолого-педагогічні науки, (1), 59-63.

Про Національну стратегію реформування системи інституційного догляду та виховання дітей на 2017-2026 роки та план заходів з реалізації іiі I етапу. Розпорядження Кабінету Міністрів України від 9 серпня 2017 р. No 526-p. URL: https://www.kmu.gov.ua/ ua/npas/250190226(дата звернення: 11.11.2019).

Про хід виконання указів та доручень Президента України з питань надання якісних соціальних послуг сім'ям $з$ дітьми. (2021). [Електронний ресурс]. Режим доступу: http://www.president.gov.ua/docs/zvit_2612.pdf C. 10.

Психологічні аспекти корекційної роботи з дітьми-сиротами в умовах інтернатного закладу: науково-методичний посібник. (2008). За ред. Л.Д. Покроєвої. Хар-ків: Хонмібо, 84 с.

Реформа інтернатних закладів (деінституціалізація). (2020). [Електронний pecypc]. Режим доступу: https://www.adm-km.gov.ua/?page_id=40310.

Реформа системи інтернатів. (2020). [Електронний ресурс]. Режим доступу :http://reform.diplatform.org.ua/.

Рогальська-Яблонська, І. П., \& Білик, Р. М. (2019). Гендерна соціалізація вихованців закладів інтернатного типу: теоретичний аспект питання. Bulletin of the Cherkasy Bohdan Khmelnytsky National University. Series" Pedagogical Sciences", (12).

Роговська, О. О., Гонтар, М., \& Новікова, С. (2019). Догляд та виховання дітей в умовах, наближених до сімейних, як інноваційний механізм деінституалізації. [Електронний ресурс]. Режим доступу: http://eir.pstu.edu/bitstream/handle/ 123456789/24706/\%D0\%92\%D1\%96\%D1\%81.2019\%D1\%82.4_p55-

60.pdf?sequence $=1$.

Седляр, Н. О. (2017). Реінтеграція дітей з неблагополучних сімей в умовах школи-інтернат. 
Словник української мови: в 11 т. (1973). АН УРСР; Ін-т мовознавства; за ред. І. К. Білодіда. К.: Наук. думка, 38.

Слозанська, Г. І. (2016). Забезпечення доступу до соціальних послуг в умовах об'єднаних територіальних громад. Social Work And Education, 3(2), 92-102.

Слозанська, Г. І. (2017). Правове забезпечення процесу надання соціальних послуг в умовах об'єднаної територіальної громади. Обліково-аналітичне забезпечення розвитку місиевих громад: збірник тез доповідей Міжнародної науково-практичної конферениї, 110-113.

Слозанська, Г. І. (2017). Упровадження посади фахівця із надання соціальних послуг населенню в умовах об'єднаної територіальної громади: труднощі, що виникають. Вісник Луганського національного університету імені Тараса Шевченка. Педагогічні науки, (1 (1)), 267-276.

Сокоринська, М. Ю. (2019). Особливості соціалізації дітей-сиріт в постінтернатний період.

Улунова, Г. Є. (2006). Психологічна корекція ускладненого спілкування в учнів шкіл-інтернатів.

Чому інтернати шкідливі для дітей. (2021). [Електронний ресурс]. Режим доступу: http://openingdoors.org.ua/ua/boardings

Шевченко, С. М. (2019). Діяльність спеціальних шкіл-інтернатів для дітей із порушеннями слуху (1991-2000).

Шелевер, О. (2014). Феномен насилля над дітьми, які виховувались в неблагополучних сім'ях. 407-408.

Ящук, І. П. (2001). Формування життєвої компетентності особистості старшокласників загаль-ноо світніх шкіл: дис... канд. пед. наук: 13.00.07. К., 210 с.

Browne, K. D. Hamilton-Giachritsis, C. E., Johnson, R., Agathonos, H., Anaut, M., Herczog, M., Keller-Hamela, M., Klimackova, A., Leth, I., Ostergren, M., Stan, V., \& Zeytinoglu, S. (2004). Mapping the number and characteristics of children under three in institutions across Europe at risk of harm. (European Union Daphne Programme, Final Project Report No. 2002/017/C), Birmingham, England: University Centre for Forensic and Family Psychology.

Browne, K. D., Hamilton-Giachritsis, C. E., Johnson, R., Ostergren, M., Leth, I., Agathonos, H., Anaut, M., Herczog, M., Keller-Hamela, M., Klimackova, A., Stan, V., \& Zeytinoglu, S. (2005a). A European Survey of the number and characteristics of children less than three in residential care at risk of harm. Adoption and Fostering, 29 (4): 1-12.

Lydiah, I., Peter, O., \& Moses, P. (2020). Psychological effects of early enrollment to boarding primary schools on pupils 'academic performance in Malaya sub-country, Kenya. Quantum Journal of Social Sciences and Humanities, 1(3), 33-41.

Mazzone, A., Nocentini, A., Menesini, E. (2017). The Bullying in Institutional Care project (BIC) partners. Bullying in Institutional care for children: Qualitative findings from four European countries. World Anti-Bullying Forum - 2017. [Електронний 
pecypc]. Режим доступу: http://www.wabf2017.com/wpcontent/uploads/2017/04/1016-Angela-Mazzone.pdf> (2017, May, 7-9).

Meli, D. (2019). The boarding school syndrome: possible effects of attending primary education boarding schools on later life choices (Bachelor's thesis, University of Malta).

Nykolaieva, V. (2019). Аналіз факторів та ризиків, що впливають на ефективність реформи деінституціалізації закладів для дітей в Україні. Manager. Bulletin of Donetsk State University of Management, 84(3), 44-54.

van Ijzendoorn, M. H., Bakermans-Kranenburg, M. J., Duschinsky, R., Fox, N. A., Goldman, P. S., Gunnar, M. R., ... \& Zeanah, C. H. (2020). Institutionalisation and deinstitutionalisation of children 1: a systematic and integrative review of evidence regarding effects on development. The Lancet Psychiatry, 7(8), 703-720.

Voronkevych, O., \& Chopyk, S. (2019). Psychological aspects of social employee's work with exciters of boarding schools. Social work and education, 6(1), 8-18. 


\section{FUNCTIONING OF BOARDING SCHOOLS EGATIVE IMPACT ON PUPILS}

Hanna Slozanska, Doctor of Pedagogical Sciences, Associate Professor, Head of the Pedagogy and Social Work Department, HEI "Ukrainian Catholic University", Lviv, Ukraine; annaslozanska@gmail.com

Nadiia Horishna, PhD, Associate Professor, Department of Social Work, Special Education and Management of Socio-Cultural Activities, Ternopil Volodymyr Hnatyuk National Pedagogical University, Ternopil, Ukraine; nadiiahorishna@yahoo.com

Abstract. The relevance of the article is highlighted by the implementation in Ukraine of the second stage of institutionalization reform, which provides for the transformation of the system of residential institutions and the development of alternative forms of family arrangements in Ukraine. The purpose of the article was to reveal the functioning of residential institutions in Ukraine and determine the impact of residential care on the personality of children. The method of document analysis was used to search, select, analyze and summarize data from statistical and analytical reports, regulatory documents, scientific articles, conference abstracts and other materials on the topic of research. The search for documents was carried out in the databases "Legislation of Ukraine", Web of Science, PsycINFO, Google Scholar and ResearchGate, on the official websites of state and local authorities. Data analysis was carried out in three categories: functioning of boarding schools, problems of children in residential care, deinstitutionalization of boarding schools.

The analysis of the boarding school system functioning in Ukraine has proved its unprofitability and inconsistency with the needs of children. Staying in residential institutions negatively affects the mental, intellectual, emotional, speech and physical development of children as well as their ability to social integration and adaptation in society. The success of the deinstitutionalization reform depends on the development of high-quality social services to support families with children at their place of residence, the introduction of alternative forms of family arrangements.

Key words: boarding schools; boarding schools' pupils; residential care, deinstitutionalization; family upbringing; social worker.

\section{References}

Balakireva, O. M., Yaremenko, O. O., Dudar, N. P. \& others. (2000). Pupils of boarding schools about themselves and their lives. K.: Ukrainian Institute for Social Research, Book. 1. 134 p. (in Ukrainian). 
Berezhna, L. (2013). To the problem of socialization of orphans and children deprived of parental care in boarding schools. Humanitarian Bulletin of the State Higher Educational Institution Pereyaslav-Khmelnytsky State Pedagogical University named after G. S. Skovoroda. Pedagogy. Psychology. Philosophy, (28 (1)), 14-18. (in Ukrainian).

Bilyk, R. M. (2019). Socialization of pupils of boarding schools as a sociopedagogical problem. Bulletin of the Cherkasy Bohdan Khmelnytsky National University. Series "Pedagogical Sciences", (10-11). (in Ukrainian).

Bondarenko, Yu. (2009). Life competence of pupils of boarding schools. Pedagogy of formation of creative personality in higher and general school. Zaporozhye, (2), 5256. (in Ukrainian).

Gordienko, N. (2018). The problem of bullying in student groups of boarding schools: a sociological aspect. European Political and Legal Discourse, (5, Iss. 1), 201209. (in Ukrainian).

Horishna, N. M. (2019). A family-oriented approach to social services providing to families raising children with disabilities. Sociology and social work in terms of national and regional dimensions, 11 (1), 24-25. (in Ukrainian).

Gritchina, A. I. (2011). The content, forms and methods of forming the readiness of young people in boarding schools to play the role of a future family man. Theoretical and methodological problems of education of children and students: 3b. Science. works, 2 (15), 134-141. (in Ukrainian).

Deinstitutionalization and transformation of services for children. (2009). K.: Kalita Publishing House, 193 p. (in Ukrainian).

Deinstitutionalization. (2020). [Electronic resource]. Access mode: https://www.msp.gov.ua/timeline/Deinstitucializaciya.html. (in Ukrainian).

Dementieva, I. (2003). Social adaptation of orphans. Social pedagogy. No. 2, 64-73.

Deryabo, S., \& Yasvin, W. (1999). Attitude to health and a healthy lifestyle: a method of measurement. School principal. No 2., 7. (in Ukrainian).

Eremina, L. E. (2019). Socio-pedagogical conditions for the formation of boarding school students' readiness for family life (Doctoral dissertation, National Academy of Pedagogical Sciences of Ukraine). (in Ukrainian).

Hare, O. M. (2019). Psychological readiness of boarding school students to start a family. Recommended by the Academic Council of Mykola Gogol Nizhyn State University (NDU named after Mykola Gogol) Minutes № 4 dated 24.10. 30. (in Ukrainian).

Report on the implementation by the Commissioner of the President of Ukraine for the Rights of the Child of a monitoring study of the functioning of institutions for orphans and children deprived of parental care, children who do not have the necessary conditions for family upbringing and education, children with special needs, efficiency of such institutions budget funds aimed at ensuring their activities (in pursuance of the 
Order of the President of Ukraine № 1-1 / 1852 of July 22, 2013). (2021). [Electronic resource]. Access mode: http://www.president.gov.ua/news/27816.html. (in Ukrainian).

Zubeyko, G., \& Vasyliv, SS (2018, October). Foster care as a form of placement of children deprived of parental care. In the 76th Student Scientific and Technical Conference. Section of Law and Psychology: a collection of abstracts (pp. 149-150). Lviv Polytechnic Publishing House. (in Ukrainian).

Kanishevskaya, L. V. (2012). Research of the problem of education of social maturity of senior pupils of boarding schools. Pedagogical Almanac, (16), 213-220. (in Ukrainian).

Kanishevskaya, L. V. (2007). Scientific and methodological bases of formation of life competence of pupils of boarding schools. Formation of life competence of pupils in boarding schools: scientific method. way. $\mathrm{K}$.: Pedagogical thought, 5-36. (in Ukrainian).

Kiyanitsa, Z. P. (2008). Socio-pedagogical aspects of the work of the service of reintegration and socialization of graduates of boarding schools as a component of the structure of integrated social services for vulnerable children and families. 79 -84. (in Ukrainian).

Kiyanitsa, Z. P., \& Petrochko, Zh. V. (2017). Social work with vulnerable families and children: pos. at 2 o'clock; Part 1. Modern landmarks and key technologies. (in Ukrainian).

Kiz, O. B. (2003). Formation of psychological readiness of pupils of boarding schools to creation of a family. (in Ukrainian).

Kiptilaya, Yu. V. (2020). Socio-pedagogical prevention of interpersonal conflicts of adolescents in a boarding school. (in Ukrainian).

Korinna, G. O. (2019). Readiness of boarding school students for family life as a socio-pedagogical problem. Bulletin of the Cherkasy Bohdan Khmelnytsky National University. Series "Pedagogical Sciences", (10-11). (in Ukrainian).

Kruglova, O. O., \& Tishchenko, I. O. (2014). The role of the institute of guardianship and care in ensuring the rights and interests of children in modern conditions. Scientific Bulletin of Dnipropetrovsk State University of Internal Affairs, (4), 159-165. (in Ukrainian).

Kuzmina, E. (2011). The specifics of the formation of life competence of pupils of boarding schools. Editorial Board, 103. (in Ukrainian).

Lebedev, O. E., \& Neupokoeva, N. I. (2002). Goals and results of school education: a method. recom. SPb.: SPGUPM, 52 p. From Wikipedia https://en.wikipedia.org/wiki/\%D0\%A8\%D0\%BA\%D0\%BE\%D0\%BB\%D0\%B0\%D1\%96\%D0\%BD\%D1\%82\%D0 \% B5\% D1\% 80\% D0\% BD\% D0\% B0\% D1\% 82. (in Ukrainian). 
Mashkarinets-Butko, A. (2013). Features of development of children-pupils of boarding schools. Scientific Bulletin of Uzhhorod National University. Series: Pedagogy. Social Work, (27), 116-119. (in Ukrainian).

Mashkarinets-Butko, A. (2019). Consideration of international practice of reforming the system of boarding schools and accumulation of this experience for Transcarpathia. The purpose of deinstitutionalization is to realize the right of every child to a family: Ministry of Social Policy. URL: https://www.msp.gov.ua/news/15560.html. (in Ukrainian).

Guidelines for improving the maintenance and upbringing of children in children's boarding schools on the principles based on the UN Convention on the Rights of the Child. (1998). [emphasis: L.S. Volynets, O. G. Antonova-Turchenko, I. B. Ivanova, N. M. Komarova, I. V. Pesha, S. M. Trusova]. K .: Studtsentr, 190 p. (in Ukrainian).

7.7 billion a year is spent on boarding schools, and $15 \%$ goes to children. (2021). [Electronic resource]. Access mode: http://nbnews.com.ua/ua/news/103058/.

National strategy for reforming the system of institutional care and upbringing of children for 2017-2026 National Strategy for Reforming the System of Institutional Care and Upbringing of Children for 2017-2026 (2021). [Electronic resource]. Access mode: https://mon.gov.ua/ua/osvita/zagalna-serednya-osvita/navchannya-ditej-uspecialnih-zakladah-osviti/nacionalna-strategiya-reformuvannya-sistemi-internativ. (in Ukrainian).

Ostrovich, E. S. (2018). General characteristics of the deinstitutionalization process in Ukraine. Prykarpattya Legal Bulletin, 2 (1 (22)), 35-39. (in Ukrainian).

Petrochko, Zh. V. (2016). Family-oriented approach in social work. Scientific notes [Nizhyn State University. Nikolai Gogol]. Psychological and pedagogical sciences, (1), 59-63.

On the National Strategy for Reforming the System of Institutional Care and Upbringing of Children for 2017-2026 and the action plan for the implementation of its first stage. Order of the Cabinet of Ministers of Ukraine dated August 9, 2017 No. 526r. URL: https://www.kmu.gov.ua/ ua / npas / 250190226 (access date: 11.11.2019). (in Ukrainian).

On the implementation of decrees and instructions of the President of Ukraine on the provision of quality social services to families with children. (2021). [Electronic resource]. Access mode: http://www.president.gov.ua/docs/zvit_2612.pdf P. 10. (in Ukrainian).

Psychological aspects of correctional work with orphans in a boarding school: a scientific and methodological manual. (2008). For order. L.D. Cutting. Kharkiv: Honmibo, 84 p. (in Ukrainian).

Reform of boarding schools (deinstitutionalization). (2020). [Electronic resource]. Access mode: https://www.adm-km.gov.ua/?page_id=40310. (in Ukrainian). 
Boarding school reform. (2020). [Electronic resource]. Access mode: http://reform.diplatform.org.ua. (in Ukrainian).

Rogalskaya-Yablonskaya, I. P., \& Bilyk, R. M. (2019). Gender socialization of boarding school students: theoretical aspect of the issue. Bulletin of the Cherkasy Bohdan Khmelnytsky National University. Series "Pedagogical Sciences", (12). (in Ukrainian).

Rogovskaya, O. O., Gontar, M., \& Novikova, S. (2019). Care and upbringing of children in conditions close to family, as an innovative mechanism of deinstitutionalization. [Electronic resource]. Access mode: http://eir.pstu.edu/bitstream/handle/123456789/24706/\%D0\%92\%D1\%96\%D1\%81.201 9\%D1\%82.4_p55-60.pdf?sequence=1. (in Ukrainian).

Sedlyar, N. O. (2017). Reintegration of children from disadvantaged families in a boarding school. Dictionary of the Ukrainian language: in 11 volumes (1973). USSR Academy of Sciences; Inst. Of Linguistics; for order. I. K. Bilodid. K .: Nauk. opinion, 38. (in Ukrainian).

Slozanska, H. I. (2016). Providing access to social services in the conditions of united territorial communities. Social Work And Education, 3 (2), 92-102. (in Ukrainian).

Slozanska, H. I. (2017). Legal support of the process of providing social services in the conditions of a united territorial community. Accounting and analytical support for the development of local communities: a collection of abstracts of the International scientific-practical conference, 110-113. (in Ukrainian).

Slozanska, H. I. (2017). Introduction of the position of a specialist in providing social services to the population in the conditions of a united territorial community: difficulties that arise. Bulletin of Luhansk Taras Shevchenko National University. Pedagogical Sciences, (1 (1)), 267-276. (in Ukrainian).

Sokorynska, M. Yu. (2019). Features of socialization of orphans in the postboarding period. Ulunova, GE (2006). (in Ukrainian).

Psychological correction of complicated communication in boarding school students. Why boarding schools are harmful for children. (2021). [Electronic resource]. Access mode: http://openingdoors.org.ua/ua/boardings. (in Ukrainian).

Shevchenko, S. M. (2019). Activities of special boarding schools for children with hearing impairments (1991-2000). (in Ukrainian).

Shelever, O. (2014). The phenomenon of violence against children raised in disadvantaged families. 407-408. (in Ukrainian).

Yashchuk, I. P. (2001). Formation of vital competence of the personality of high school students of general world schools: dis .... cand. ped. sciences: 13.00.07. K., 210 p. (in Ukrainian).

Browne, K. D. Hamilton-Giachritsis, C. E., Johnson, R., Agathonos, H., Anaut, M., Herczog, M., Keller-Hamela, M., Klimackova, A., Leth, I., Ostergren, M., Stan, V., \& 
Zeytinoglu, S. (2004). Mapping the number and characteristics of children under three in institutions across Europe at risk of harm. (European Union Daphne Programme, Final Project Report No. 2002/017/C), Birmingham, England: University Centre for Forensic and Family Psychology.

Browne, K. D., Hamilton-Giachritsis, C. E., Johnson, R., Ostergren, M., Leth, I., Agathonos, H., Anaut, M., Herczog, M., Keller-Hamela, M., Klimackova, A., Stan, V., \& Zeytinoglu, S. (2005a). A European Survey of the number and characteristics of children less than three in residential care at risk of harm. Adoption and Fostering, 29 (4): $1-12$.

Lydiah, I., Peter, O., \& Moses, P. (2020). Psychological effects of early enrollment to boarding primary schools on pupils 'academic performance in Malaya sub-country, Kenya. Quantum Journal of Social Sciences and Humanities, 1(3), 33-41.

Mazzone, A., Nocentini, A., Menesini, E. (2017). The Bullying in Institutional Care project (BIC) partners. Bullying in Institutional care for children: Qualitative findings from four European countries. World Anti-Bullying Forum - 2017. [Електронний pecypc]. Режим доступу: http://www.wabf2017.com/wpcontent/uploads/2017/04/1016-Angela-Mazzone.pdf> (2017, May, 7-9).

Meli, D. (2019). The boarding school syndrome: possible effects of attending primary education boarding schools on later life choices (Bachelor's thesis, University of Malta).

Nykolaieva, V. (2019). Аналіз факторів та ризиків, що впливають на ефективність реформи деінституціалізації закладів для дітей в Україні. Manager. Bulletin of Donetsk State University of Management, 84(3), 44-54.

van Ijzendoorn, M. H., Bakermans-Kranenburg, M. J., Duschinsky, R., Fox, N. A., Goldman, P. S., Gunnar, M. R., ... \& Zeanah, C. H. (2020). Institutionalisation and deinstitutionalisation of children 1: a systematic and integrative review of evidence regarding effects on development. The Lancet Psychiatry, 7(8), 703-720.

Voronkevych, O., \& Chopyk, S. (2019). Psychological aspects of social employee's work with exciters of boarding schools. Social work and education, 6(1), 8-18. 